\title{
EDITORIAL
}

\section{Creativity and Creative Industries in Europe and Beyond}

This issue is devoted creativity as such and creative industries in Europe and beyond. European Union (EU) institutions now make the creative industries one of its official industrial strategy sectors and have rightly highlighted the creative industries as a key sector for Europe not only economically but socially and culturally. The European Commission's role is to ensure that the culture sector is able to increasingly contribute to employment and growth across Europe. It priorities in the field of cultural and creative industries include responding to changing skills needs by promoting innovation in education, supporting the mobility of artists, coordinating with EU states to reform regulatory environments and developing policies and initiatives, to promote market access for and investment in creative industries. The growing meaning of such tendency is a result of increased digital technologies and the economic crisis of the past years.

Baltic States live in this "new normality" and try to find own niche. Laura Laurušaite analyses from the view of glocalization compare experiences and achievements of three Baltic countries in the field of creative industries, present similarities and differences on this way. Her conclusions show that the Latvians are concentrating their efforts on the formation of the theoretical potential, design of development strategies; the Lithuanians are most intensively developing the educational aspect of creative industries: they are working on new study modules and train multifunctional specialists - future practitioners potentially capable of speeding up the symbiosis of business and creative work; the Estonians are leaders in the practical field of innovation, offer original and competitive products to the market, especially in the sphere of information technologies, which attract foreign investors. This article shows us a visible and invisible tendencies and give possibility rethink Lithuanian lost or may be not enough used possibilities on European market. From my view, Tomas Mitkus' and Vaida Nedzinskaitè-Mitkè's article is an optimistic case about the Lithuanian film industry and these cultural and economic aspects of the national and global situation and developments in the 21st century. The authors evaluate the symbolic and cultural national film industry output level and show Lithuanian innovative marketing practice. Czech authors - Lukáš Danko, Pavel Bednáŕ, Jana Matošková - show own national possibilities to gain insight in benefits of institutionalized cultural and creative clusters and determinants as well as barriers of their development based on cluster managers' activities in the Visegrad countries. They underline that such character as level of openness, approach to life-long learning, previous experience, communication skills, and involvement in mutual cooperation were identified as predominant determinants of cultural cluster development. Jolita Šliogerienė and Giedrè Valūnaitè-Oleškevičienè try to answer on very important 
question what it means "good teaching" in nowadays times. The article stresses the importance of creativity in higher education and explores the expression of teacher creativity while using social media in university studies. The research is based on HansGeorg Gadamer's philosophical approach and presents an overview of teacher "lived experience" that reveals the elements influencing their creativity. Aleksander Sautkin article from first glance stay alone through others but in reality it expresses another side of creativity which is more spontaneous and unlimited. For him subcultural creativity is reviewed as an important differentiating factor of the previous ideological integrity, turning into some contradicting parts. The case of black metal subculture is actively sets itself in opposition to the dominant culture. Loqman Radpey and Gregory Rose with their article subject invade in unknown too much sphere of political events in which he found a newly constitution as example of creative thinking and political practice. Using descriptive-analytic approach, he describes the articles of the constitution to reveal how national minorities claim may be the model for the rest of Syria through a "democratic federalism". Seungbae Park article devoted individual and selective realism as scientific theories. Author concluded that the historical episode concerning the humoral, miasma, theory, and germ theories exhibits that creative scientists were not selective realists but individual realists. For him, individual realism creates a more favorable atmosphere than selective realism for the advent of new theories. South Korean researcher KyongMi Paek adds that contemporary artists working in ecological realms have presented distinct ways of understanding ecological concerns and proposed creative solutions to environmental challenges through ingenious means that reach people beyond scientific realms. This article aims to expand art's potential role via reports on a recent curriculum development study of an on-campus collaborative art project in which practicing artists known for their bioregional orientations were invited to inspire engineering students. These three collaborative projects presented in Paek's article draw common image of cultural creativity in the time of ecological crisis.

Unlocking the potential of cultural and creative industries is a good tour in the future from a social, cultural and educational perspectives. In the XXI century creativity itself have not boundaries and restrictions. Gilles Deleuze underlined that art, science and philosophy are neither contemplative, neither reflexive, nor communicative, they are creative. 